\title{
1. A climacteric of corporate crisis and over-reach
}

\section{INTRODUCTION}

In 1983 the directors of a middling English, top-tier football club, Tottenham Hotspur, scented the wind of market forces stirred by Thatcherite economics. They converted the club's status into a public limited company (plc). By the attendant listing on the London Stock Exchange (LSE) they aimed to bring in millions of pounds from a share issue. This income could be used to 'buy' expensive, quality players to give the team a competitive edge in fighting for trophies. The scheme succeeded in attracting some new capital, but not for winning many trophies. By 1999 twenty top clubs in professional English football had become plcs. The collapse of the international investment bubble in 2000, and clubs' inability to convert massive TV incomes into consistent share dividends, diminished the attractiveness of corporate status. Most clubs subsequently 'de-listed' but their removal into the sphere of big business was irreversible. Many became private businesses bought and owned by rich benefactors, speculators or overseas corporations. Some, like Manchester United, continued listing to exploit their international brand recognition and tap more overseas investors. As of 2014 Manchester United was listed on the New York stock exchange (NYSE) had an income of $£ 420$ million, operating costs of $£ 373$ million and debts of $£ 350$ million. Directors were exultant about selling the brand to mass audiences in North America and more shares to investors on the NYSE (Guardian 2014).

Yet in the opinion of business professor (and Everton FC supporter) Tom Cannon, formerly of Manchester Business School and the City of London's Gresham College, the corporate model is totally unsuited to the running of football clubs. Many United and other fans no doubt share this opinion as they have witnessed profits accumulate but match ticket prices escalate and, in many cases, playing fortunes deteriorate. Football and sports are not alone in being taken over by the corporate model and its ethos. Plcs or their executive management systems have taken over 
swathes of public and social activities throughout Britain. In the terminology of the German sociologist Jurgen Habermas, they have colonised the lifeworld. The significance of this penetration was recognised by a former French economy minister. Arnaud Montebourg alleged that internet giants such as Facebook and Amazon had made databases usable for almost tax-free commercial gain and exploitation by US intelligence experts. A German minister, Sigmar Gabriel, wrote:

Every ... 'search' for something on Google ... captures information about ourselves which can not only be sold for targeted personalised advertising, but is, essentially, also available to our bank, our health insurance company, our car or life insurance company, or - if the need arises - to the secret service. (Garside 2014)

Even allowing for some political hyperbole, such dominance indicates corporate over-reach; an excess manifested in the increased frequency and range of big business scandals and crises.

The tide of corporate over-reach actually intensified after 2007, with the wider economic depression - which can itself be attributed to the irresponsibility of the corporate sector's financial wing. The tsunami of corporate crisis spans its own economic domain, as well as environmental, political, civil rights and social welfare spheres. Irresponsibility and financial mendacity on corporations' own turf are a glaring aspect of broader corporate over-reach: the power to exploit position for advantage. It is chiefly this economic aspect that has provoked various segments of the political class into prescriptive critiques and even business representatives themselves to call for more integrity and responsibility. Thus, John Cridland, the Director-General of the Confederation of British Industry, identifies a public rejection of corporate 'poor performance and perceived excess'. Yet he recommends as solutions only 'more transparency' by each firm ("produce an A4 page of narrative to explain exactly what [tax] it's paying', Heath and Fournier 2013), plus competition and closer identification with 'the customer' (Guardian 2013b). Financial editor and policy adviser Martin Wolf is more specific. He assesses the corporation as 'the core institution of contemporary capitalism ... a brilliant social invention', but with 'inherent failings':

the most important of which are that companies are not effectively owned. That makes them vulnerable to looting. Incentives allegedly provided to align the interests of top employees with those of shareholders, such as share options, create incentives to manipulate corporate earnings ... Shareholder control is too often an illusion and shareholder value maximisation a snare, or worse. (Wolf 2012) 
For remedies, Wolf alludes to: 'other forms of ownership, including partnerships and mutual ... genuinely independent, diverse and wellinformed boards', 'pay packages [that] are transparent' and removal of 'destructive forms of remuneration'. But he concludes that 'governments should not intervene directly'. The political parties are more dramatic in their diagnoses, but hardly more radical in their prescriptions. Wolf's ownership flaw is a conundrum that has been at the centre of much academic research in corporate power and societal subordination. It is outlined in broad terms in chapter 2 and probed for its relevance to corporate reform in the final two chapters.

The present work links this and other key pillars of corporate power to critical areas of corporate over-reach beyond their market remits and beyond the economic domain altogether, into the spheres of politics and social relationships. However, a preliminary idea of the scale of the problem can be gleaned from considering just the environmental, international social and financial problems created by corporate over-reach. Repeated environmental disasters are particularly notorious hallmarks of corporate over-reach. This history includes emblematic flashpoints such as: the Union Carbide (now Dow Chemicals) explosion at Bhopal, India in 1985; the BP oil-rig explosion in the Gulf of Mexico in 2012; and persistent abuse in, often illegal, deforestation of tropical rainforests driven by logging for hardwoods, and major western food corporations' demand for cattle pasture and palm oil plantations.

Persistent social and political controversies have included a saga from the 1980s over Nestlé's infant milk substitute in developing societies; continuing fallout from the persecution of Ogoni protestors against Shell's Nigerian oilfields since 1987 (Rowell et al. 2005, p. 83-84); and exploitation and human rights abuses amongst Western multinationals' supply chains in the global South. Long-standing supply chain scandals culminated horrifically in the inadequate monitoring, by brands such as Primark, Matalan and Benetton, of the Dhaka factory which collapsed in Bangladesh (with 1,100 deaths) in April 2013. The more insidious financial crises have ranged from fraud and collapse in multinational banks, the 2001-02 accounting frauds at Enron, Tyco and WorldComm in the USA; through bribery cases involving UK weapons and aerospace contractors BAe (2006/7) and Rolls Royce (2013); plus allegations of price-fixing by energy companies such as Shell and BP in 2012. Banking corporations' malpractices have become major political crises: pricefixing of the LIBOR inter-bank lending rates in 2012, illicit lending and investment practices since the millennium precipitating bank collapses, the crash of the global financial system and international economic recession from 2008. Yet executives continue to receive exorbitant 
salaries and bonuses, even in unprofitable corporations. More fundamentally, the fiscal crisis resulting from the financial crash has generated swingeing welfare cuts in developed economies. Yet excess public debt is caused, at least partly, by tax avoidance by a host of multi-national corporations (MNCs), including Amazon, Boots, Google, Starbucks, Topshop, and Vodafone in 2013.

Space constraints prevent a more comprehensive account of corporate misdemeanours but bear in mind also the cases of: illegal information gathering by news corporations (see the 2012 UK Leveson Inquiry), mis-sold financial products, and illegal meat foods and so on. Since this book went to press others will certainly have occurred. Twenty years ago such patterns might be attributed to a 'few rotten apples', or a rash of 'swindlers', 'looters', or 'predators' deviating from normal standards to take advantage of relatively free markets and lenient regulation (Bakan 2004 , p. 1). Now it seems more plausible to see wayward power and autonomy as a systemic problem, which stems from the nature of the corporate institution itself. Concentrations of power and massive finances are, of course, always likely to generate frauds, misdemeanours and catastrophes. However, the frequency and range of scandals, executive self-interest and abuse, seem more consistent with inherent faults. The grand scale of malfeasance can be traced back to a common source: the expanded scale of corporate activity tantamount to a monopoly of power, not just in the economy but throughout society. Scholars describe this capacity as: instrumental power - ability to realise a specific interest or advantage, structural power - limitation of politicians' capabilities by dependence on business consent or agendas, and, finally, discursive power - ability to define the ideas and terms in which issues are addressed and debated (cf Fuchs 2007, pp. 56-63). The rest of this chapter maps the contours of these powers through their economic and political dimensions, firstly in general terms and then with reference to the specifics of the UK polity and society.

\section{ECONOMIC AND SOCIO-POLITICAL HEGEMONY}

I begin my Corporate Power course at the University of Bath by asking students to $\log$ the corporate products and services they have used or encountered in the past 24 hours. The usual lists amount to between 30 and 60 competing or complementary products and brands, from toiletries through foods to phones and financial services, ending with entertainment, such as sports and television. Three or four giant corporations usually figure in each consumption category, from Starbucks to 
Sainsburys, Levis to Lynx, or Microsoft to Manchester United. It only takes students a few minutes to recollect about 16 aspects of their daily lives that depend upon corporate products and brands; and these are relatively low spending students. In higher spending demographics corporate penetration of daily life, with dependence on their products and services, is probably much greater. From that first sip of corporate water in the morning to switching off the energy-oligopoly lighting before sleep, corporate products and services permeate and structure our daily lives. This 'colonisation of the lifeworld' in Habermas's apt metaphor (Habermas 1981), is the visible tip of an iceberg of socio-economic dominance and political hegemony spanning social institutions and civic life. Corporate dominance stems from economic power over social life and its institutions; but, in turn, these businesses' exceptional legal and political privileges extend and consolidate that supremacy.

\subsection{Economic Scale}

MNCs make up 70 per cent of the world's foreign trade total of US \$7 trillion (UNCTAD). In the USA the top 500 industrial corporations control 'over two-thirds of the business resources ... and collect over 70 per cent of all US profits (Share the World's Resources 2007; OECD 2013a). The internet was originally a publicly organised but semispontaneous, even anarchic, realm of individual self-expression. But it has since become a vivid illustration of the expanded scope of the corporate world. The migration of commerce, personal communications, entertainment, information gathering and sharing to the internet represents a major slice of the corporate colonisation of social and personal life. In the past couple of decades, both the operation of web services and their content have become more closely guarded spheres of corporate influence, control and market exploitation (Consalvo 2003; Dahlberg 2004).

It has been claimed that online, social media offer considerable scope for civil society actors and protesters to mobilise, organise and campaign against political overlords and corporate power itself. However, this argument tends to overlook the fact that these online arenas are now provided and facilitated by the giant internet corporations. They can limit and, in conforming to governmental diktats, have limited the scope of popular dissent and protest. Moreover, in pursuit of other commercial gains, big businesses have begun to shape social media participation to their own ends, as the allegations against Google, Amazon and Facebook in the Introduction indicate. Marketing advisers have gleaned from the most active business users of online communications that: 
... social media-based conversations occurring between consumers are outside managers' direct control. This stands in contrast to the traditional integrated marketing communications paradigm whereby a high degree of control is present. Therefore, managers must learn to shape consumer discussions in a manner that is consistent with the organization's mission and performance goals. (Mangold and Faulds 2009, p. 357)

These and other corporate practices have been induced by the increasing dominance of the mega corporations, such as Microsoft and Google, as the industry has become more concentrated (Shah 2009). More general corporate levels of concentration are reflected in international trade. By 2007 there were 43,060 transnational corporations, as compared to 7,000 in 1969 when concern at their growth was first expressed (cf Vernon 1971, 1977; Tugenhadt 1973). But even within the multinational domain there has since been concentration. In 200920 per cent of global revenues were owned by just 1,318 of those $43,060 \mathrm{MNCs}$, and through shareholdings they owned most of a further 60 per cent of global revenues. A mere 147 companies form a 'super entity' controlling 40 per cent of the wealth of this elite group of 1,318. All own part or all of one another (Vitali et al. 2011). To illustrate their financial power, critiques of corporate status usually make invidious comparisons of their wealth and incomes with those of sovereign nation states, as in Table 1.1.

Admittedly, statistical comparisons of corporate and state economies, based on their sales revenues and GDPs respectively, risk conflating two different measures: essentially the (lower) value added in national economies with the (higher) transactions incomes of businesses. Grahame Thompson has shown that this conflation artificially magnifies the relative size of the corporate economies vis-à-vis the national ones (Thompson 2003, p. 407). Perhaps what matters more is the capacity to use such resources and the scope of their use. In other words: the freedom to spend their gains on things which achieve major outcomes. States seem to have substantial freedom of choice in their spending: on welfare, warfare or widgets. Corporations' priorities, on the other hand, are relatively fixed: wage bills, production, creditors and shareholders. Contrarily, some states are highly constrained by their constitutions, electoral protocols or - increasingly - their own indebtedness. Yet some firms have achieved such economic hegemony that their fiscal autonomy is restricted only by the limited concerns of their shareholders. In the end this is an empirical question for different states and companies, beyond the present study. However, even if caveats such as Thompson's are accepted, the relative potency of corporate resources is still formidable. 
Table 1.1 Comparison of nations'GDP with corporate revenues, 2010

\begin{tabular}{lc}
\hline Company/Country & Revenues/GDP (\$ billions) \\
\hline Norway & 414 \\
Wal-Mart Stores & 408 \\
South Africa & 364 \\
Greece & 305 \\
Exxon Mobil & 285 \\
Chevron & 164 \\
Romania & 162 \\
General Electric & 157 \\
Peru & 154 \\
Bank of America Corp & 150 \\
ConocoPhilips & 140 \\
Ukraine & 138 \\
AT\&T & 123 \\
Ford Motor & 118 \\
J.P. Morgan Chase \& Co & 116 \\
Hewlett-Packard & 115 \\
Berkshire Hathaway & 112 \\
Bangladesh & 112 \\
Citigroup & 109 \\
Verizon Communications & 108 \\
McKesson & 107 \\
General Motors & 105 \\
Vietnam & 104 \\
Tesco (2011) & 60 \\
Sri Lanka & 59 \\
\hline &
\end{tabular}

Source: www.globalpolicy.org/images/pdfs/Comparison_of_Corporations_with_GDP_ of_Countries_table.pdf

At the peaks of these corporate Himalayas the really big corporations, such as Apple, Walmart and Exxon-Mobil in the USA, or the UK based Tesco, Shell or HSBC, have both size and the financial clout to exert major influence not only in their market sectors, but also in civil society 
and public spheres. Apple's financial wealth of $\$ 76.4 \mathrm{bn}$ in 2011 , as measured by cash balances, was greater than that of the entire US government (Investment Week 2011). Although this was a temporary situation, Apple still has enormous cash reserves for diverse investments. It 'shelters' its profits overseas, beyond the reach of US tax authorities, and these can then be invested worldwide. Ironically, 'it holds $\$ 21 \mathrm{bn}$ of US government debt - a vast sum for a single private investor' (Guardian $2012 b$ ). This holding is more than Malaysia's $\$ 19 b n$ and only $\$ 4 b n$ less than Spain's entire investment in US debt. The US's Walmart retailer and the UK's Tesco have sales revenues of $\$ 444$ billion and $\$ 113$ billion respectively (Institute for Global Labour and Human Rights, 2012).These sums compare favourably with the UK government's total income tax revenue of $£ 152 / \$ 246$ billion (National Statistics dataset - HM Revenue and Customs receipts) in the same year.

Masses of individuals depend on such firms for employment. Numbers vary by the products and services sold, but the biggest MNCs command vast armies of workers. Walmart's 2.2 million labour force is exceeded only by the numbers serving the US Defence Department (3.2 million) and the Chinese Red Army (2.3 million). Not far behind is McDonalds 1.7 million (Economist 2011) with the UK-based G4S marshalling 620,000 worldwide. A different type of corporate entity, Foxconn (also known as Hon Hai Precision Industry Co Ltd) has been estimated to employ around 1.2 million. Intriguingly, this Taiwanese firm has no significant public face in the West. It concentrates on manufacturing about 40 per cent of the content of the world's popular electronic consumer goods, like smart phones and portable computing devices. The lack of visibility of this concealed hinterland of Western brand corporations is reflected in the fact that Foxconn's employment figures are also estimates. Yet many of these workers are a kind of surrogate labour force for western MNCs as their labour is devoted mainly to the manufacture of Apple products. Indeed campaigners have forced the US corporation to take some tacit responsibility for exploitative working conditions (Guglielmo 2013). The sales and marketing reach of MNCs is now becoming almost global, extending to some of the most remote communities on the plant. By a clever alliance with NGOs and rural self-help groups, Unilever, the world's largest producer-supplier of hygiene and personal care goods, has extended its sales into the 70 per cent of India's one billion people who reside in rural villages accessible only by dirt roads, motorcycles or bullock cart (Rangan and Rajan 2007). 


\subsection{Political Influence}

Such market power justifies widespread concern about competition, consumer dependence and labour rights. But international, often global, economic strength also seems to translate into - and partly derive from power or influence in the political sphere. The international spread of a neo-liberal market system, following the so-called Washington Consensus and based on the Plaza Accords of 1985, strengthened the influence of corporations, especially financial ones, within international economic governance. The establishment of the open-market World Trade Organization (WTO) in 1994 through 'the twin drives of managing the trade rivalry among the leading industrial countries and containing the threat posed by the South to the prevailing global economic structure', effectively enshrined openness to MNC trade (Bello, n.d.). By pressuring the national governments which make up the WTO membership, MNCs were able to help shape its overall framework of 'equal' trade treatment and were given opportunities for lobbying for specific measures and cases (Jones 2004; Sell 1999).

Following this Washington Consensus on open markets and tariff reductions, plus the rise of neo-liberal ideology and policy, the current international trade system secured special advantages for corporations in governance institutions such as the WTO. By increasingly 'offshoring' operations to countries with weak or indifferent regulatory powers, MNCs have effectively insulated themselves from the potentially tougher rules of the states in which they originate (Cutler 2006, p. 207). On wider concerns, such as environmental policies, coalitions of MNCs have proven effective adversaries in forums such as the United Nations (Newell and Levy 2006, p. 160). MNCs have found a particularly congenial political environment in the governance structures of regional economic blocs such as the European Union and North American Free Trade Association. In the latter body, business groups managed to secure a constitution which grants 'foreign companies more rights than domestic citizens' (Colgan 2005, p. 109; Lewis 1993).

Summarising a diverse literature, Fuchs (2007) notes the disproportionate participation of MNCs and their representatives in international regulatory forums for technology (warfare technologies/bio-technologies), intellectual property, and environmental policy, as well as the bodies through which national governments try to exercise global economic governance: the IMF, WTO and the United Nations. Cautioning that mere presence does not necessarily translate into achievement of goals, Fuchs nevertheless points out that MNCs have superior resources for information and expertise generation and can outbid the punier claims of labour, NGOs 
and even (inter)governmental organisations (Fuchs 2007, pp. 84-91). The evolution of the European Community into the European Union has meanwhile created a cornucopia for corporate lobbying and advantage-seeking. Between 20,000 and 30,000 (mostly business oriented) lobbyists work on about 20,000 EU officials, spending $€ 60$ billion to $€ 90$ billion a year within the EU, mainly in Brussels (Coen 2009). The 'public relations industry' is itself, of course, organised in large corporations. At one point, four such businesses controlled 50 per cent of the world's market for PR (Miller and Dinan 2003).

These and other operators have been increasingly influential in shaping the interface between policy and scientific agendas. For example, the authoritative sounding International Life Science Institute (ILSI) is a lobby group funded by 'hundreds of the biggest food, pharma and chemical companies', such as Coca Cola. It became part of the World Health Organization's investigation of dietary sugars 'by covertly funding some of the scientists involved' (Miller 2008). Particularly striking evidence of corporate influence comes from the tobacco industry where big tobacco firms persuaded other sector leaders to form an alliance to change the basis of EU policy making. From 1995 onwards British American Tobacco led an alliance of corporations which 'altered the way in which all EU policy is made, by making a business-oriented form of Impact Assessment mandatory', Thereby tilting EU policy making towards the interests of major corporations, including firms whose products involve health risks (Smith et al. 2010, p. 1).

These product-related and market-specific interventions have a tenuous legitimacy as intrinsically business concerns. But as their economic influence and operating scope has increased, corporations' 'discursive power' (Fuchs 2007, p. 149) has been heightened. Domhoff (1990) associated institutional networks of corporate executives and professionals not only with upper class concentrations of wealth but with policyshaping networks of business-friendly foundations and think tanks. With the added discursive power of these networks, corporations have sought to shape wider policy areas and political agendas - particularly environmental and social ones. Inter- and trans-governmental action on climate change is probably the broadest of these environmental concerns. As Jacques et al. (2008, p. 362) observe, 'the strategy has shifted from defence of single companies or industries (such as tobacco or pesticides) to using sceptics to challenge environmental science in general'.

The means of achieving such strategies may be indirect. In the USA corporate financing of parties or individual politicians is a favoured channel. But at least as important is the complementary discursive impact which energy corporations have gained by seeking 'to undermine climate 
science via lobbying and participation in the now inactive Global Climate Coalition (GCC) as well as by directly funding CTTs (Conservative Think Tanks) and sceptical scientists' (Kolk and Pinkse 2007, p. 206). Such interventions have penetrated and influenced a swathe of mass and specialist media communications as well as legislatures (Levy and Egan 1998, p. 147-8; Layzer 2007). Significantly, however, business finds it difficult to speak with one voice on climate change. Some MNCs calculate more influence derives from eschewing outright opposition in favour of more responsive approaches involving 'market' solutions that ameliorate carbon emissions in profit-friendly ways (Kolk and Pinske 2007). Nevertheless in international policy making, Farnsworth and Holden (2006, p. 482) argue that discursive power is overwhelming.

International business has helped to establish a consensus ... that has shifted policy agendas, including those of the major IGOs, towards a more probusiness one. As a result, the EU's competitiveness agenda is almost identical to the key demands made by international business and, where policies to control the negative aspects of corporate activities have been proposed ... strong lobbying from business has ensured that only voluntary codes of conduct have so far been introduced.

The United States, plus the UK, still acts as policy model for neoliberalising societies elsewhere; and, in that country, business lobbying and political influence have become all-embracing. By the late 1990s the number of individual corporations with lobbying bases in Washington had risen from the 165 in 1968 to over 600; with these and others also represented through trade and industry associations.

Marshalling these separate forces is the Business Roundtable, representing 200 CEOs of large and giant corporations and credited with reversing the spate of social and environmental reforms of the Kennedy, Johnson and Nixon eras, and channelling neo-liberal, de-regulatory pressures. This free-marketism led, inter alia, to the Washington Consensus through the business-friendly administrations of Regan, Clinton and the Bush family. Following successive favourable Supreme Court verdicts, big business was also able to outbid other organisations in the funding of Political Action Committees which sponsor individual politicians, including presidential candidates. Corporations were the next highest donors to these 'super' PACs, after rich individuals - themselves probably having corporate wealth (Fuchs 2007, pp. 74-83; Barnes 2012; Demos 2012).

One of the most signal indicators of corporate influence over political actors is the benevolent lassitude with which governments and their fiscal apparatus have tolerated corporate tax avoidance. Multinationals have 
been able to use and/or misapply those rules. Even the 'capitalist club' of developed market economies, the OECD, warned these arrangements have allowed MNCs:

to separate income from the economic activities that produce that income and to shift it into low-tax environments ... from transfers of intangibles and other mobile assets for less than full value, the over-capitalisation of lowly taxed group companies and from contractual allocations of risk to low-tax environments in transactions that would be unlikely to occur between unrelated parties. (OECD 2013a, pp. 19-20)

States' tax administrations, the OECD observes: 'have little capability of developing a "big picture" view of a taxpayer's global value chain' p. 22). Even while presenting a business-friendly tax reduction philosophy, US President Obama acknowledged that 'empirical evidence suggests that income-shifting behaviour by multinational corporations is a significant concern' (US Treasury 2012, p. 7). UK politicians have been more forthright. Parliament's Public Accounts Committee stated,

'Multinational companies appear to be using transfer pricing, payment of royalties for intellectual property or franchise payments to other group companies to artificially reduce their profits in the UK or to remove them to lower tax jurisdictions.'

This Committee's Report added, archly, 'We were not convinced that HMRC has the determination to robustly challenge the practices of these companies' (UK Parliament 2012, para 1.6). Such official reports indicate governmental tolerance of systemic corporate tax evasion. More partisan accounts allege extensive cooperation verging on collusion between tax authorities, politicians and corporate representatives like accountancy firms (Corporate Watch, 2010; Hodge/Public Accounts Committee, 2013). Even though fiscal capacity is a central pillar of nation states' functions, it seems that its workings, as in other areas of corporate over-reach, have been damagingly penetrated by the culture and political influence of big business.

\section{SCALE AND HEGEMONY IN THE UK}

Measured by output and value-added, five or fewer firms dominated, with at least 70 per cent of the UK market, for: sugar, tobacco products, gas distribution, oils and fats, confectionery, man-made fibres, coal extraction, soft drinks and mineral waters, pesticides, weapons and ammunition. Similar concentration levels applied in airlines, banking, and accountancy (ONS 2006, pp. 26-7). Strong reasons for associating this 
dominance with the growth of ST/EM corporations comes from the calculation that the proportion of the capital market (total shareholdings of publicly quoted companies) of the top 100 FTSE firms rose from 68.36 per cent in 1988, to 87.77 per cent in 2008 (Leone and Philp 2010, p. 16). ${ }^{1}$ Around half of UK GDP in the 1980s and 1990s was attributable to business corporations and at least 80 per cent of that value came from bigger stock market quoted companies (Froud et al. 2000b, pp. 773-4).

Of course, UK residents shouldn't need such esoteric indicators to recognise the dominance of MNCs. Personal finance is dominated by four banks. Barclays, HSBC, Lloyds Group and RBS hold 77 per cent of all personal bank accounts (as well as 85 per cent of small business ones - International New York Times 21 July 2014). Alternatively consumers can stroll down high streets dominated by the likes of Vodafone, Everything-Everywhere (Orange/T-Mobile), '3' and O2 for mobile phone networks, and McDonalds, Burger King, Pizza Hut and KFC for fast foods. They probably buy from one of the big three grocery retailers: Tesco, Sainsbury, Asda/Walmart (totalling 65 per cent of grocery retailing), and choose online between Google, Yahoo, Bing (totalling 97.5 per cent), to buy from Ebay and Amazon; having selected internet service provision from the four internet service providers (BT, Virgin Media, Talk-Talk, Sky) that supply 87 per cent of UK internet connections (Guardian, 2011). Big businesses tend to get bigger by taking over other businesses. Since the 1980s, however, and especially in the UK, they have also grown by taking over and financing state activities and public services. This expansion constitutes over-reach in the sense that it has not been merely - some would argue not at all - a rational process of economic and democratic policy making. As the following account shows, expansion into public services is a crucial manifestation of corporations' acquisition of political power and influence.

\subsection{The Capture of Public Services}

Starting with the Thatcher governments of the 1980s and accelerating through the New Labour and Coalition governments, firms have taken over the provision of what used to be state-sector services such as health and education. Corporate giants such as Capita - 16,936 employees, $£ 1.08$ billion sales in 2012 - mushroomed in a few decades throughout the expanding outsourcing of internal and public service functions. These were added to contracts for ancillary services such as cleaning and catering and the longer-standing supply of private-sector goods, such as pharmaceuticals and medical equipment for the operation of public sector services. Neo-liberal international economic consensus on limiting state 
borrowings has led governments to look to the business sector to help finance their own capital expenditures. So construction for health, education and infrastructure has been paid for by long-term debt schemes such as the Private Finance Initiative (PFI), which leases hospitals, schools and other buildings to the public sector. At local levels, councils have been required to contract out the management and service delivery, a process reinforced by local public-private partnerships and central government financing conditional on projects involving partnerships with the private sector (Coulson, 1997, p. 34; Coates et al. 2000).

Long-term care is now predominantly provided by the private sector. Private companies have also been taking over some NHS services: some hospital trusts and general practice surgeries. The 2012 'reform' of the NHS by the Conservative-Liberal Democrat Coalition opened up further tracts of its services to medical and health care businesses. On one estimate, 70 per cent of NHS contracts awarded since the reforms were won by private firms (Health Service Journal 2014). Some of these businesses, such as United Health (paying out $\$ 820$ million dividends) are multinational or, like Beresford Health (a division of HCPro Inc.), owned by MNCs like Halyard Investments. With contracting out of parts of local educational services to private firms, and with the spread of state licensed school academies and 'free schools', business ownership is being promoted for basic education (Groves 2014; Independent 2014). Under New Labour (1997-2008) local employment services were taken on by private firms such as Reed in Haringey, Newham and Liverpool, and Pertemps in Birmingham (Farnsworth and Holden 2006). Under the controversial 'Work' programmes all (re)employment services were contracted out to 18 'prime providers' corresponding to English and Welsh regions. Of these, some were small national or regional businesses. But four firms had more than three contracts and five were MNCs, like SERCO, Igneus and mega-employer G4S (UK Government 2013). On one estimate one third of all government services are now outsourced (Julius 2008).

The case for this increasing spread of corporate business provision through public services and welfare entitlements is that the status of the providing organisation is irrelevant to the quality of the provision. If private business can give a service that is equal to, or more effective than a public organisation, then business should have that opportunity (Whitfield 2001). The corporate case is enhanced by the presumption that business is usually more efficient than public 'bureaucracies': its managers more proactive and skilled, its workforces more responsive and flexible and its cost consciousness usually higher. But the real political trump card is that outsourcing and privatisation reduce public expenditure 
and the size of the state's budget deficit: an over-riding political criterion for the international fiscal system and its neo-liberal watchmen. The case against rests on the inappropriateness of applying business logic to services founded on ethical and civic values of care, equality or social solidarity. Businesses, this counter-case points out, have an over-riding aim of profit making and, if organised as corporations, a duty to privilege the interests of their shareholders. Consequently, in areas of uncertainty, financial ends will displace humanitarian ones.

More generally, carers lack the autonomy from commercial-managerial pressures to privilege the needs of patients, welfare recipients, or other dependants. Staffing itself will be subject to rigorous controls reducing the ratio of carers per recipient, minimising their training and hiring on the basis of wage costs rather than professional expertise. On one recent estimate 70 per cent of care home staff are effectively casual workers employed on so-called 'zero-hours' contracts (Guardian 2013b). A string of scandals involving inadequate staffing and care levels in residential homes, disability assessments, medical help lines, prison services and control of asylum seekers, lend weight to these charges. Legal judgements also mean that recipients of privatised services do not have the same rights as those where the provider is a public body: for example Human Rights legislation or access to corporate records under the Freedom of Information Act for care home residents (McFadyean and Rowland, 2002; Reporters Committee for Freedom of the Press, 2007).

As other cases illustrate (see chapters 9 and 10), businesses' commercial priorities can over-ride the need for reliability and stability in public facilities and services. Crises of investment, overly frugal employment policies, and managerial turnover are all more likely in the private sector. Some of the giant oligopolies which have inflated to take on a range of public service contracts - firms like Capita, Compass, Interserve, Serco, and Sodexo - have been associated with such disruptions. The stability of Four Seasons Health Care, 'Britain's largest health care chain', has been twice shaken by the kind of financial turmoil which can beset the financial border zones of the corporate sector, experiencing debt crises and take-overs (Guardian 2012b). Major service failings have also been attributed to a customer-contract ethos which is incompatible with the carer mentality required for many sensitive public services. Operating with reduced staffing in order to lower costs, so as to win contracts and make profits, has also been cited as a source of poor services. The Southern Cross company was censured for neglect associated with mismanagement and understaffing in its Orchid View care homes after its descent into bankruptcy in 2011 (Wachman 2011). On the business side such public service contractors have defied even the logic of shareholder 
value by proliferating their range of businesses, thus becoming the kind of 'unfocussed conglomerates' alleged to be anathema to investment analysts. As in other sectors, critical questions have also been raised about the size of executive remuneration paid for managing what are near-monopolies. But, perhaps most significantly, corporate operation of public services has made the latter more remote from the levels of transparency and accountability expected of the public sphere (cf Harris 2013).

\subsection{Shaping the Policies which Determine Public Services}

Welfare reforms, like those to Disability Allowance, controversially carried through by private sector operators, have been linked back to the influence of commercial insurance companies during the New Labour governments of 1997-2010 (Black Triangle Campaign 2011). Corporate leverage on public service policy has become particularly pronounced in the continuous capture of the National Health Service by commercial firms. The new Conservative ministers in the 2010 coalition government soon announced a restructuring to allow more private sector 'competition' into NHS service provision. But it was corporate health businesses which influenced both the policy perspectives behind the new model and also the negotiations on the details of the actual legislation (Leys and Player 2011). It seems unlikely to have been coincidental that some executives of Monitor, the NHS regulator, were former employees of McKinsey, the all-encompassing consultancy and advocacy business. McKinsey's influence in the UK goes back as far as the firm's almost single-handed conversion of the internal structure of UK corporations into the US multi-divisional model during the 1960s and 1970s (see chapter 3). More recently McKinsey personnel had a role in writing sections of the eventual Parliamentary bill for the NHS restructuring even though the firm has business links to some of the very commercial providers likely to secure contracts from the 'new' NHS. Despite usually being a staunch pro-Conservative newspaper, the Daily Mail reported that:

many of the Bill's proposals were drawn up by McKinsey and included in the legislation wholesale $\ldots$ the firm has used its privileged access to 'share information' with its corporate clients - which include the world's biggest private hospital firms - who are now set to bid for health service work. (Daily Mail 2012)

The Mail also reported that McKinsey executives attended and even hosted meetings of the 'Extraordinary NHS Management Board which 
implements the legislation. Yet McKinsey's receives "millions" of pounds from advising GPs on the reform Bill's implications ... and earned at least $£ 13.8$ million from Government health policy since the Coalition took office.' Lord Carter of Coles, head of the NHS regulator, the Co-operation and Competition Panel, also had extensive health business interests, including chairing American healthcare firm McKesson, according to the Mail.

Care UK, a division of a US MNC, made significant donations to the Conservative party, including $£ 21,000$ to the personal office of Andrew Lansley - the Minister who designed the details of the legislation (Huitson 2012). More egregious still was the UK Coalition government's recruitment of former New Labour adviser Simon Stevens from US MNC United Health where, as its 'president of global health', he worked to intensify market contracting of medical professionals (Forbes 2013).

In other public policy sectors, such as energy and foodstuffs, multinational corporations do not quite decide government policies. Yet it is certainly a big help to them that the unofficial Multinationals Chairmen's Group - reputedly representing firms like BP, British American Tobacco, Diageo, GlaxoSmithKline, Shell, Unilever and Vodafone - frequently meet the Prime Minister on matters of joint concern (Cave and Rowell 2104, p. 59). Their advice may not always be taken, but their representatives staff the advisory and policy bodies in which policy approaches and criteria are established. A recent investigation found, for example, that scientists funded by food multinationals staff the advisory bodies for health guidelines for sugar intake associated with the escalating obesity epidemic (Boseley 2013). More disturbingly, for expectations of a healthy, pluralistic policy environment, corporate interests have infiltrated the processes of debate and research. The campaigner George Monbiot has claimed corporations, such as the health-to-foodstuffs MNC Unilever, may use their ethical and CSR credentials to influence policy formation on development, environment and health issues through representation on national and international governmental forums: from Scientific Advisory Committees, through G8 bodies, to the UN's 'High Level Panel on global development' (Monbiot 2014a). As Cave and Rowell have documented, this trend is one which now encompasses the lobbying forces of corporations across the food, drink and energy sectors (Cave and Rowell 2014, pp. 75-77). The dynamics of these sectors will be examined in chapters 4 and 10 respectively.

The expansion of government outsourcing and privatisation of services in the past two decades has been shaped by business involvement in 
policy bodies such as the Institute for Public Policy Research. This notionally left-of-centre think tank was originally established as a counter to the powerful influence of neo-liberal bodies such as the Adam Smith Institute and the Centre for Policy Studies. By 1999, however, its 'Commission on Public Private Partnerships' was being funded by the global accountancy and consulting firm KPMG, BT plc, Serco, Nomura Bank (owner of Hyder Business Services), Norwich Union Mill Group (Norwich Union PLC), and Group 4 (Whitfield 2001, p. 34). These businesses were already involved in advising, contracting for, or participating in public spending and PFI projects and local authority strategic partnerships. Coincidentally, the Commission defined its aim as setting out 'a reform programme aimed at ensuring that in the future PPPs are used at the right times and to maximum effect.' It claimed to be 'open minded about the contribution that partnerships could make to public services', but to distance itself from: 'a perspective which holds that as a matter of principle public services should always and everywhere be provided by the public sector' (IPPR 2001).

Further privatisation-oriented policy output included 'private spending on healthcare' (sponsored by Norwich Union Healthcare and Genus Pharmaceuticals - Gosling 2008, p. 25). The influential New Local Government Network ('frequently called on to advise government on everything from city deals to neighbourhood community budgets') also receives funds from Serco, Jarvis, BT, KPMG, as well as Carillion, Nord Anglia Education plc, Amey, Sodexho, Capita, Arthur Andersen (Whitfield 2001, p. 37), and 'partners' with BT and Vertex, Serco, Amey, Kier, PricewaterhouseCoopers and PA Consulting (Gosling 2008, p. 25); all commercially involved in outsourcing and contracting. In 2008 the New Labour Government set up a Public Services Industry Review chaired by DeAnne Julius - fortuitously a senior non-executive director of the giant contracting firm SERCO - one of the 50 per cent of the review body members who were 'senior managers or business representatives (Wilks 2013, p. 139).

Other research policy organisations range from virtual in-house think tanks such as the Aldridge Foundation (ex-Capita) and the SERCO Institute, through PricewaterhouseCoopers' 'Public Sector Research Centre' ( sponsor of the Demos think tank on 'public service codesign'), the Social Market Foundation on 'the death of deference' in health and education services, another IPPR project ('Public Services at the Crossroads'), and the New Local Government Network's 'incentives for councils to build major infrastructure projects'. By 2008 the UNISON report on the Public Services Industry could list 17 former ministers, MPs, and civil servants who had taken up paid posts with businesses 
involved in the PFI, health and public services contracting 'industries' (Gosling 2008, p. 28-9). There is a growing inequality of political influence between all of these modes of corporate interest promotion and the political system's declining responsiveness to public and civil society voices.

This inequality confirms that the problem of corporate power affects the very heart of liberal democracy. Big business does not just have the power to influence politics: corporations are themselves political actors. Moreover: 'Not only are corporations political actors, their political power is exerted on an everyday basis as part of our political system' (Wilks 2013, p. 41). The legitimacy of such roles must have been boosted by the 2014 appointment of John Manzoni, former oil executive and non-executive director of the giant multi-national brewer SABMiller, as the government's first ever chief executive of the civil service. Manzoni's former boss at the controversial petrochemicals giant BP, John Browne, had already been appointed as 'lead non-executive' director on the Cabinet Office board, as part of a plan to install 'non-executive directors', most likely business or ex-corporate leaders, onto the boards of all government departments (BBC News 2010, 2014). The reality of notions of pluralist democracy has always been highly debatable, but in the wake of so much corporate over-reach, its plausibility verges on fantasy.

\section{PENETRATION OF CIVIL SOCIETY: CORPORATIONS AS PATRONS}

Corporate colonisation of the public realm extends beyond the take-over of public services. Through their recent adoption of Corporate Social Responsibility (CSR) programmes, explored in chapters 8 to 10, corporations are starting to dominate the charity and voluntary organisation networks, analogous to the patron-client regimes of allegedly 'backward' or pre-modern societies (see Jones 2007). Moreover, the wider sponsorship of artistic and sporting events and programmes gives corporations influence over the character of these activities. As described in the introduction to this chapter, in sports such as football, the direct annexation of clubs occurred via conversions into share-traded ples and the adoption of the commercial traits - financial dealings, marketing, management structures - of more mainstream corporations (Political Economy of Football n.d.).

Barclays Bank has a typically panoptic use of sponsorship to promote its business identity. The aforementioned English football Premier League is branded as the Barclays Premier League and the bank is also 
the official sponsor of key football bodies in the UK, including the Football Writers' Association, the League Managers' Association and just to square off the football circle - the Professional Footballers' Association. These affiliations form part of a worldwide stable of sponsorships including Barclays' Absa subsidiary in South Africa, which sponsors South Africa's national football team, and the country's Absa Premiership domestic football competition. Other sports 'captured' include tennis (the Barclays ATP World Tour Finals at London's 02 Arena), golf (the Fed-Ex Cup on the PGA Tour in the United States) and the South African Springboks national rugby team. These, essentially brand marketing, tentacles spread down into local communities through 200 Barclays 'community sports sites' for over 40 different sports in China, Hong Kong, India, South Africa, Spain, the UK, the USA, Zambia and Zimbabwe.

In the wider art and entertainment world, Barclays sponsors includes the Barclaycard Mercury Prize for UK (pop music) Albums of the Year and, to spread its profile into high-culture middle class consumers, the avant-garde Donmar Warehouse theatre, exhibitions at the British Museum and the Victoria and Albert Museum, plus the main venue for the Hay-on-Wye Festival, 'the world's pre-eminent literary and arts festival'. More prosaically, an astute sponsorship of the Mayor of London's Cycle Hire scheme ensures that the bank's name and logo circulate throughout the capital's streets. Barclays also claims to be a 'partner' of the Metropolitan (London) Police, hosting community policing events at its local branches (Barclays Entertainment Sponsorships 2014). All of this sporting and community presence no doubt helps to compensate in the public mind for a series of regulatory and taxation penalties against Barclays for attempting to manipulate: the US electricity market, for which it was fined $£ 299$ m by the US Federal Energy Regulatory Commission, the London Interbank Offered Rate (Libor) $£ 59.5$ million fine - and the Euro Interbank Offered Rate (Euribor); as well as UK tax avoidance repaid at a cost of $£ 500$ million (Wilson 2012, 2013; Treanor 2012). Moreover, as we shall see in chapters 8 to 10, this nakedly commercial sponsorship blends seamlessly into apparently 'ethical' programmes of CSR.

\section{SOME STRUCTURAL OUTCOMES}

As both corporate advocates and some grudging critics accept, their organisational capacities have made MNCs, as Commonwealth Secretary-General Don McKinnon put it, the 'most powerful force for 
global technology transfer, skills development and international investment flows' (UK Parliament 2002a). Its financial advantages are patent.

The company is one of the West's great competitive advantages ... Companies increase the pool of capital available for productive investment. They allow investors to spread their risks by purchasing small and easily marketable shares in several enterprises. And they provide a way of imposing effective management structures on large organizations. (Mickelthwait and Wooldridge 2003, p. xxi).

Short of revolutionary transformation, governments, families, communities and many civil society organisations could not function without corporate products and services. Such dependence makes corporations' imminent removal, or transformation of their economic roles, highly unlikely. This immense capacity for meeting contemporary needs - at least amongst the developed world's institutions and populations - stems from the mobility of capital both between financial corporations and cognate businesses and internally within MNCs. They can increasingly move freely around the globe in search of both market opportunities and the least restrictive operating and profit-making conditions. But there are serious and growing consequences of the exercise of these powers on employment standards and governments' capacity to pursue social welfare programmes, or policies on the environment and culture (CAFOD in UK Parliament 2002b). Disproportionate corporate power is also making it increasingly difficult for the economically advanced societies to fulfil their official ideology of liberal democracy, and for newer capitalist and market societies to realise these democratic institutions. As indicated above, the democratic deficit from the power of TNCs to influence policy makers at national and international levels is widening alarmingly.

Corporations have also been decisive for the coalescence of a new ruling elite, which, on several accounts, constitutes the disproportionate wealth and influence intensifying inequality in societies like the USA and UK. The present analysis does not explore this social divide itself. The financialised elite's nature and power has already been documented with elan by Savage and Williams (2008, pp. 1-24) and in its corporate manifestations by Wilks (2013, pp. 64-94). My main concern is with the organisational structures which gestate and sustain these elites. Just as the medieval theocratic and aristocratic elites depended on their religious orders and manorial estates for their power, so today's financial and business elites would be stranded weaklings if dismounted from their corporate steeds.

These broader social considerations stem from an observation by management guru Peter Drucker, that the corporation is 'the first 
autonomous institution in hundreds of years, the first to create a power centre that was within society yet independent of the ... government ... of the state' (Drucker 2002, p. 156). Insofar as the state represents the wider society, we can deduce therefore that corporations are in society but not of society. The various forms of corporate excess and malfeasance indicate a common problem of 'corporate over-reach', which can be summarised as follows.

- Not following markets but neutralising market processes (mergers and acquisitions, inter-corporate collusion etc).

- Extending their power into shaping political and government policy making.

- Taking over public services via privatisations and outsourcing (e.g. Capita and G4S).

- 'Colonising' civil society by, e.g., expanding charitable and sponsorship relations (often justified as CSR).

\section{CONCLUSION}

In other words, business corporations have been taking on roles and powers for which they were neither designed nor originally authorised. As a result there is widespread concern, not confined to radical critics of capitalism, that ST/EM corporations' activities now constitute a threat, not just to economic stability and wealth distribution, but to the integrity of the societies they dominate and, as chapter 9 describes, to the environmental conditions on which humans and other life-systems depend (Mayer 2013, p. 161; Wilks 2013, pp. 267-8). The question to which we now turn is what are the historical structures which have facilitated this rise to malign dominance?

\section{NOTE}

1. The volatility of share prices on the stock exchange means that quoted share capital is not a reliable measure of the underlying economic value of corporate assets. But then again, all price-based figures are relative to a specific time and situation. 